\title{
Emblem of the Polish Republic as Part of the National Culture: The Genesis of the Symbol ${ }^{2}$
}

\begin{abstract}
The theme of this article is the evolution of the Polish national emblem. Without knowledge of the genesis and history of this national symbol, it is difficult to understand the value of education in terms of nationality and the sense of national unity. Appearance, shape, colour evolved due to the political centrifugation in the country, but always and invariably meant Poland as the home of those who lived in the country and emigrated.
\end{abstract}

\section{Keywords:}

national emblem, Poland, coat of arms, national symbols

It is natural to change the national emblem as well as the national constitution, especially when the state is based on new principles. The symbol of the eagle has been used by the Polish sovereigns for about 1000 years. The Polish coat of arms, representing an image of a crowned white eagle, has been present for 700 years (Jaworska, 2003). In times of monarchy, the coat of arms was changing together with sovereigns. Nowadays, alterations of the national coat of arms are

1 University of Rzeszow.

2 The text is a modified version of the speech at the International Scientific Conference Statehood and Symbolics in Central Europe after 1989, Budapest, 2 October 2009. 
rare. Introduction of a new coat of arms symbolizes changes within the state. The current coat of arms in the Republic of Poland has been used - though not without modifications - for about 80 years. Only slight modifications of such important national symbol, introduced during intense structural transformation in the 20th century, can be surprising. Three ideologically different states adopted very similar coats of arms. However, the similarity is illusory. Adding or removing any elements often raised strong emotions among Polish people. Complex understanding of the symbolism of the Polish coat of arms requires consideration of its origin.

\section{THE EMBLEM AND THE COAT OF ARMS OF THE REPUBLIC OF POLAND}

Traditionally, the emblem of Poland represents a crowned white eagle. The symbol of an eagle appeared for the first time on the coins made during the reign of Bolesław Chrobry, after his coronation in 1025. The crown on the eagle's head has symbolized the state's unity and sovereignty since the beginning. The symbol of a white eagle has been used as the emblem of Poland since 1295, i.e., since the reign of Przemysł II (Znamierowski, 2003).

Apart from a lion, an eagle is one of the most commonly used animal motives in heraldry. The image of a lion has been typical for the Western European area whilst the symbol of an eagle has been frequently adopted in the central and partially the southern part. The symbol of an eagle in the 13th century could be found not only in the Polish emblem, but also in the emblems of Brandenburg, Tyrol, Czech, Moravia, Silesia, Opole, Krakow, Modena, and Kraina. As an animal dominant in the air, an eagle symbolizes bravery, strength and courage. The eagle in the Polish emblem is traditionally represented in a combat position with outstretched wings and open beak. Moreover, typically for emblems, the eagle's beak and talons are unnaturally big. Although the emblem placed on the heraldic shield is named as the White Eagle, the eagle is actually silver. It is consistent with the rules of applying and defining colours in heraldry (Znamierowski, 2003).

The emblem, placed on a special shield, is defined as a coat of arms. The Polish coat of arms, i.e., the White Eagle, is traditionally placed on a red heraldic shield. The shape of heraldic shields has evolved from a Normand shield in the 13th century to a French shield from the 18th century. The current coat of arms of the Republic of Poland uses the French shield. It should be stressed that the white eagle on the red shield is the Polish coat of arms, not the emblem (Znamierowski, 2003). Nonetheless, incorrect definitions can be found in many Polish legal acts regulating the national symbols. 


\section{THE EMBLEM OF POLAND}

The Polish people consider the white eagle not only as a state symbol but also as a national symbol. Such conviction has been initiated at the end of the 14th century, when the Polish-Lithuanian Commonwealth was established by the personal union between the Kingdom of Poland and the Grand Duchy of Lithuania. Since the Union of Lublin was concluded, the so called Commonwealth of Both Nations was established. As a result of the transformation, the Polish coat of arms was modified in order to include both, Polish and Lithuanian symbols (Znamierowski, 2003). The coat of arms of the Polish-Lithuanian Commonwealth combined their previously separate coat of arms, i.e., the White Eagle and the Chase on a quarterly parted field. The image of a white eagle ceased to be only the symbol of the state or of the sovereign and started to be the Polish national symbol.

By the 1795, the Polish-Lithuanian Commonwealth ceased to exist after it had been partitioned in three stages by the neighbouring Russian Empire, Kingdom of Prussia, and the Habsburg Monarchy. The Polish people, deprived of their own state until 1918, developed a specific worship of the white eagle, treating it as a national symbol (Jaworska, 2003). Bans imposed on the use of the white eagle by the foreign rulers only strengthened their conviction (Rosner, 2003). The white eagle was a permanent motive in literature and patriotic songs at the time. It was, and still is, used as an ornamental motive in jeweller's and applied art.

The symbol of a white eagle reappeared twice as one of the symbols adopted by unsovereign states established on the Polish area in the first half of the 19th century. The first one was the Duchy of Warsaw, established in 1807 by Napoleon. The second was the Kingdom of Poland, i.e., a Russian protectorate established in 1815 by tsar, Alexander I. The symbol of a white eagle was also used twice during two national uprisings, in 1830 and 1863 (Rosner, 2003). Also the Polish emigrants used the white eagle as a symbol of a national status. After Poland had been reestablished as an independent country on 1918, the White Eagle once again became the official emblem of Poland. However, it also remained the national symbol.

\section{POLISH COAT OF ARMS DURING THE SECOND POLISH REPUBLIC}

Directly after regaining independence, a dispute arose as to how the Polish coat of arms should look. Many Polish people supported depriving the white eagle of its crown due to the republican character of the state. The coat of arms including an eagle without a crown was introduced in 1918. However, in consequence of 
a general indignation aroused among many Poles, the coat of arms was converted into a traditional symbol of the Polish state (Górecki, 2008). The Colours and the Emblem of the Republic of Poland Act of August 1st, 1919 stipulated that "Until borders are settled, and until constitution defines state emblems, state colours, titles of the state offices and institutions, offices of the state shall use emblems and colours consistent with the following patterns: 1 . [...]The image of a white eagle with his head turned right [...] with outstretched wings, gold claws, crown and beak, on a red, rectangular field shall be the coat of arms of the Republic of Poland"3. The stylization of the Polish emblem of 1919 referred to the eagle used in the Polish coat of arms during the reign of the last king of Poland, Stanisław August Poniatowski. It should be noticed that the eagle's crown was of a closed type, topped with a cross symbolizing affection for the Christian traditions. It is worth adding that the problems connected with the issue of state symbols during the Second Republic was not regulated in constitution, although it was announced in the Colours and the Emblem of the Republic of Poland Act of 1919 (Sarnecki, 2007).

The emblem of the Republic of Poland of 1919, which was to be only temporary, was used until 1927. In 1927 it was replaced by an emblem designed by an architect, prof. Zygmunt Kamiński. The new emblem was designed as a synthesis of the Polish historical state emblems (Znamierowski, 2003). It was introduced by the decree of the President of the Republic of Poland of December 13th, $1927^{4}$. According to the Article 1(1) of the Act, "the state emblem, i.e., the image of a white eagle with his head turned right [...], with outstretched wings, gold crown, beak and claws [...] on a red, rectangular shield”.

The new pattern of the state emblem aroused a lot of controversy, not only due to its modern stylization. It was pointed that the emblem contained formal errors: the band on the eagle's wings and his paws should be gold, the crown should have a cross at the top, the eagle's image should be flat with black contour lines instead of bulging, ends of the band on the eagle's wings should be shaped as a three-leaf because five-leaf is associated with a Bolshevik or a Mason star, and the shield should not have a gold frame (Znamierowski, 2003). In spite of numerous critical comments, the emblem introduced in 1927 is used until the time being. It has been

3 Ustawa z 1 sierpnia 1919 r. o godłach i barwach Rzeczypospolitej Polskiej, Dz.U. [JoL] 1919 No. 69, item 416 (Journal of Laws of the Republic of Poland, abbreviated Dz.U., is the official journal for promulgation of laws in Poland).

4 JoL 1927 No. 115, item 980. 
modified many times due to structural transformations. Nonetheless, it has been used for over 80 years, i.e., the longest time in history.

Although during the World War II the Polish territory was under occupation, legal Polish authorities operated abroad, initially in France, afterwards in Great Britain. After the World War II, a new Polish state in alliance with the Soviet Union was proclaimed. The authorities of the People's Republic of Poland were dependent on the Soviet Union, casted aside the traditions of the II Republic of Poland and persecuted Poles who fought at the West during the World War II. All the above caused that the authorities operating abroad were acknowledged by many Polish emigrants and Poles living in the country. Their functioning after 1945 was strictly symbolical, specially due to the fact that The People's Republic of Poland was Acknowledged by the Allies. Nonetheless, one of their actions included introducing a new design of the state emblem with the decree of the émigré President of the Republic of Poland in 1956 (Znamierowski, 2003).

The coat of arms of 1956 differed due to the introduction of a closed type crown topped with a cross and new proportions of the shield. It was a reaction to the fact that the authorities of the People's Republic of Poland derogated the Act of December 13th, 1927 and introduced a new model of the coat of arms. The emigration authorities functioned until 1990, when the émigré President of the Republic of Poland , Ryszard Kaczorowski, passed the authority insignia to newly elected President of the Republic of Poland, Lech Wałęsa.

\section{POLISH COAT OF ARMS DURING THE PEOPLE'S REPUBLIC OF POLAND}

In the years 1944-1989, three types of the state coat of arms were present. The first one was used since the forties until 1955, though there were no legal regulations introducing it.

It represented the image of a white eagle with a distorted beak, deprived of a crown, placed on a red, elongated shield framed with a general wavy line. Although seemingly only slightly different from the pattern of 1927, the coat of arms differed considerably. It was deliberate and symbolized a break with traditions characteristic for the period between the two World Wars. Due to no legal regulations introducing this coat of arms, formally the coat of arms of 1927 was in force (Górecki, 2009).

The first Polish constitution which regulated the issue of the coat of arms was the Constitution of the People's Republic of Poland of $1952^{5}$. The issue of the

\footnotetext{
5 JoL 1952 No. 33, item 232.
} 
emblem, the colours and the capital was regulated in a separate ninth chapter, placed rather unfortunately at the nearly end of the legal act. According to the Article 89(1), "The image of a white eagle in a red field shall be the emblem of the People's Republic of Poland”. The Constitution described the state emblem very concisely, specifying only the fact that it refers to the tradition of the white eagle. Detailed regulations were left to the executive acts (Sarnecki, 2007).

The coat of arms of 1927 was officially derogated by a State Council's decree on the emblem and the colours of the People's Republic of Poland and the state's seals of the December 7th, 19556. According to the Article 1(1), "The image of a white eagle with his head turned right, outstretched wings, gold beak and talons in a red rectangular shield rounded at the bottom shall be the emblem of the People's Republic of Poland". The pattern of the state emblem, for the first time incorrectly named as the coat of arms in a legal act, is represented in a graphic attachment. In spite of the later modifications concerning legal acts and the emblem itself, the conceptual mistake - i.e., replacing the term 'coat of arms' with an 'emblem' - has become a permanent element in the Polish legal system and the Polish language.

The pattern of the coat of arms of 1955 was a slightly modified version of the pattern of 1927. The eagle was deprived of a crown, which manifested structural transformations and a break with tradition. The crown, which symbolized the sovereignty of the Polish state, was removed against expert's opinions (Jaworska, 2003). It unintentionally emphasized the dependence of the People's Republic of Poland from the Soviet Union. Modifications affected the shield as well. The wavy frame of the 1927 coat of arms, subjected to a strong criticism since the period between the World Wars, was removed.

Another modification of the state coat of arms took place in 1980, when a complex law on the state symbols was passed. Regulations of the Emblem, the Colours and the Anthem of the People's Republic of Poland Act of the January 31st, 1980 were preceded by a preamble which precisely defined the meaning of the state symbols for the Polish nation ${ }^{7}$. The Article 2(1) of the Act described the state coat of arms in a nearly identical manner as in the decree of 1955. Its graphical pattern, presented in the attachment no. 1, differed slightly from the previous version.

In relation to the 1955 coat of arms, the shape of the eagle's beak was corrected. However, the abovementioned modification can be considered irrelevant. The change of the end of the band on the eagle's wings is more important. The band's endings, formed in a five-leaf shape since 1927, were replaced with five-arm

\footnotetext{
6 JoL 1955 No. 47, item 314.

7 JoL 1980 No. 7, item 18.
} 
stars. Allegedly, the replacement was a result of the designer's mistake, though the explanation has not been credible. The symbol of a five-arm star was unambiguously associated and the Polish authorities had clearly pro-Russian sympathies.

\section{THE COAT OF ARMS OF THE REPUBLIC OF POLAND (1990)}

The structural transformations that took place in Poland after 1989 had a substantial character. Therefore, the fact that - unlikely to many other states of the former soviet bloc $^{8}-$ no new Constitution was passed directly after the structural breakthrough can be surprising. However, modification introduced into the Constitution of the People's Republic of Poland were so far-reaching that they are described as the constitutional revision of the constitution (Grabowski, 2008). Modifications affected the name of the state (the traditional name, the Republic of Poland, was restored) and the state symbols, including the emblem and the coat of arms.

The modified Article 103(1) of the Constitution stipulated that "The image of a white eagle in a crown in a red field shall be the emblem of the Republic of Poland"' . The regulations of the Article 3 of the Act on the revision of the Constitution of the People's Republic of Poland kept in force the validity of all the state documents prepared on forms and blanks provided with the former emblem and state name. The above regulation applied to orders, distinctions and tenders ${ }^{10}$. The Article 4(1) of the abovementioned Act allowed to prepare documents on forms and blanks provided with the former emblem and state name and to decorate with orders designed during the period of the People's Republic of Poland - until supplies ran out. The usage and issue of tenders was restricted to December 31st, $1995^{11}$. The Article 4(1) provided two temporary periods relating to the use of the emblem, which was applied until 1989. All the seals provided with the former emblem and state name were to be used until December 31st, 1995. The official boards with the former emblem and state name were to be modified until December

8 After 1989, new Constitutions were adopted in Croatia (1990), Bulgaria (1991), Macedonia (1991), Slovenia (1991), Czech Republic (1992), Estonia (1992), Lithuania (1992), Romany (1992), Slovakia (1992), Russia (1993), Belarus (1994), Ukraine (1996), Poland (1997). The Hungarian Constitution was thoroughly modified and Latvia restored the 1992 Constitution subjecting it to thorough changes.

9 Ustawa z 29 grudnia 1989 r. o zmianie Konstytucji Polskiej Rzeczypospolitej Ludowej, JoL 1989 No. 75, item 444.

10 Ibidem, art. 3.

11 Ibidem, art. 4 par. 1. 
31st, $1992^{12}$. The longest temporary period related to the military symbols, which had to be modified by December 31st, $1997^{13}$.

Detailed regulations concerning the emblem and the coat of arms were included in the Emblem, the Colours and the Anthem of the Republic of Poland Act. Similarly as in the case of the Constitution, no new legal act was adopted, but the binding act was modified ${ }^{14}$. The modifications included the Article 2(1), which was given a new wording: "The image of a white eagle with a gold crown on his head which is turned right, with outstretched wings, placed on a shield with a red field shall be the emblem of the Republic of Poland"15.

Modifications within the Act were related only to selected regulations on the emblem and the national flag. As a consequence of the above, the title of the Act as well as the unaltered regulations still used the People's Republic of Poland as the state's name. It can be surprising especially as it was an act which regulated the issue of the national symbols, modified due to the structural breakthrough. Nowadays it is hard to establish whether such fragmentary changes resulted from haste or legislative chaos connected with numerous amended legal acts. The abovementioned Article 2(1) used the Republic of Poland as the official state's name whilst the former name, i.e., The People's Republic of Poland, was left unamended in the Article 2(2), which stipulated that "The pattern of the emblem of the People's Republic of Poland is included in the attachment no. 1" ${ }^{16}$. The attachment no. 1 represented a graphic design of the new emblem, which was consistent with the description given in the Article 2(1). The neglect was not removed until 1997, when the governmental administration was reformed ${ }^{17}$.

Currently, the Emblem, the Colours and the Anthem of the Republic of Poland and the State Seals Act of January 31st, 1980 is in force. The act was amended many times. Eight amendments approved in the years 1990-2009 modified the list of subjects entitled to use the national symbols and changed the rules related to their usage.

12 Ibidem, art. 4 par. 2.

13 Ibidem, art. 4 par. 3.

14 Art. 43 par. 1 Ustawy o godle, barwach i hymnie Polskiej Rzeczypospolitej Ludowej z dnia 31 stycznia 1980 r., JoL 1980 No. 7, item 18.

15 Art. 1 par. 2 ustawy z dnia 9 lutego 1990 r. o zmianie przepisów o godle, barwach i hymnie Rzeczypospolitej Polskiej, JoL 1990 No. 10, item 60.

16 Art. 2 par. 2 Ustawy o godle, barwach i hymnie Polskiej Rzeczypospolitej Ludowej z dnia 31 stycznia 1980 r., JoL 1980 No. 7, item 18.

17 Ustawa z dnia 4 września 1997 r. o działach administracji rządowej, JoL 1997 No. 141, item 943. 
Attachment no. 1 to the Emblem, the Colours and the Anthem Act includes - as it is stipulated in the Act - the pattern of the emblem of the Republic of Poland. The term 'emblem' is incorrectly used instead of the 'coat of arms' term. The graphic attachment represents an image of a white eagle with a gold beak and talons placed on a red heraldic shield of a modern French type from the 18th century. The eagle's head is crowned, which traditionally symbolizes the state sovereignty (Jaworska, 2003) ${ }^{18}$. The idea of bringing the crown back was commonly expressed during the transformation period and was supported by specialists ${ }^{19}$. The idea expressed the will to restore the traditional image of the white eagle. The restoration of the eagle's crown was symbolic as well. It represented the breach of the ideology traditional for the People's Republic of Poland; ideology which discarded the Polish monarchist traditions by means of using the eagle without a crown. On the other hand, the pattern of the state coat of arms clearly refers to the symbolism of the period of the Second Republic of Poland (Sarnecki, 2007).

The eagle is represented in a classic combat position with outstretched wings and an open beak. The eagle's wings included a band with endings shaped as a three-leaf with additional fragmentary petals. The shape of the band's endings, never used before, was introduced in 1990, because the former endings were shaped as five-arm stars which aroused unfortunate associations.

The issue of the coat of arms was regulated in the new Constitution of the Republic of Poland of April 2nd, 1997. The Article 28(1) stipulates that "The image of a crowned white eagle upon a red field shall be the emblem of the Republic of Poland"20. The regulations of the Constitution are the same as those of 1989. Detailed regulations of the national symbols were left to other legal acts ${ }^{21}$.

\section{CONCLUSION}

The structural breakthrough that took place in 1989 resulted in modifications of the national symbols. It also affected the state coat of arms. The designs used during the period of the People's Republic of Poland were abandoned whilst patterns

18 Ibidem, pp. 6-7.

19 Stanowisko Polskiego Towarzystwa Historycznego i Polskiego Towarzystwa Heraldycznego w sprawie polskiego godła państwowego [The View of the Polish Historical Association and the Polish Heraldic Association on the Issue of Polish National Emblem], Mówiq Wieki [The Centuries Speak] 1989, 6, p. 26.

20 Konstytucja Rzeczypospolitej Polskiej z dnia 2 kwietnia 1997 r., JoL 1997 No. 78, item 483.

21 Ibidem, art. 28 par. 5. 
from the period of the Second Republic of Poland were adopted. The coat of arms of the Republic of Poland introduced in 1927 has become a prototype of both, the coat of arms of the People's Republic of Poland and the Republic of Poland reborn after 1989.

\section{References:}

Górecki, D. (2008). Symbole i stolica państwa. In: D. Górecki (ed.), Polskie prawo konstytucyjne (pp. 52-55). Warszawa: Wolters Kluwer.

Górecki, D. (2009). Godło RP (art. 28). In: W. Skrzydło, S. Grabowska, R. Grabowski (eds.), Konstytucja Rzeczypospolitej Polskiej. Komentarz encyklopedyczny. Warszawa: Wolters Kluwer.

Grabowski, R. (2008). Klasyfikacja konstytucji z uwagi na tryb ich zmiany. In: R. Grabowski, S. Grabowska (ed.), Zasady zmiany konstytucji w państwach europejskich (pp. 13-17). Warszawa: Wolters Kluwer.

Rosner, A. (2003). Prawnoustrojowe symbole Rzeczypospolitej szlacheckiej na ziemiach polskich w początkach XIX wieku. Studia Iuridica, 42, 191-203.

Sarnecki, P. (2007). Artykuł 28. In: L. Garlicki (ed.), Konstytucja Rzeczypospolitej Polskiej. Komentarz (pp. 1-4), Vol. V. Warszawa: Wydawnictwo Sejmowe. 